\title{
THE ANTIBACTERIAL QUALITIES OF CLAY, AN ECOLOGICAL OPTION FOR IMPROVING THE BUILT ENVIRONMENT
}

\author{
Gabriela Cristina Chitonu ${ }^{1}$ \\ Christiana Emilia Cazacu ${ }^{2}$ \\ Radu Muntean ${ }^{3}$
}

UDK: 666,327

DOI: $10.14415 /$ konferencijaGFS2019.048

Summary: This article looks at some of the positive qualities of clay, and how this traditional material can be an inexpensive and valuable material for buildings. It looks at historical use in Romania and the region, and aims to highlight how advanced modern technology shows us why should learn from the past. It explores additional places of use compared to the more traditional applications and reveal why this material can be considered as a high tech, sustainable and environmentally friendly material for some areas of our modern homes.

Keywords: Clay, Built environmet, Ecological

\section{INTRODUCTION}

Starting from ancient times the main element in defining a civilisation is the spatial management of its territories, its capacity at adapting to the climate and the valorisation of the natural resources. The human settlements created complex relations and changes on the natural environment. Christian Norberg-Schultz in his book: Existence, Space \& Existence, identifies the 6 levels of the existential space and describes how the built environment influences the global environment, and the necessity of balancing the natural ecosystem with the communities heritage in order to preserve the ancestral habitat. [1]

Amongst our civilisations earliest building materials, clay was discovered for its adaptability, the easy access to vast quantities of it and for its strength and ability to last and to shelter.

Clay is a natural material produced mainly from the natural destruction of rock from weathering and erosion. This finely-grained material has amongst other qualities the advantage of having a high plasticity until it is dried, allowing for easy shaping, and its

\footnotetext{
${ }^{1}$ Gabriela Cristina Chitonu, PhD arch., Transilvania University of Brasov , Faculty of Civil Engineering, Brasov, Turnului nr.5, Romania, e - mail: gabriela.chitonu@unitbv.ro

${ }^{2}$ Christiana Emilia Cazacu, PhD dipl. eng., Transilvania University of Brasov , Faculty of Civil Engineering, Brasov, Turnului nr.5, Romania, e - mail: cazacu,christiana@unitbv.ro

${ }^{3}$ Radu Muntean, PhD dipl. eng., Transilvania University of Brasov, Faculty of Civil Engineering, Brasov, Turnului nr.5, Romania, e - mail: radu.m@unitbv.ro
} 
Савремена достигнућа у грађевинарству 23-24. април 2019. Суботица, СРБИЈА

use spans from household appliances, ovens to art, construction materials and more. It is a robust material, which is stable, versatile and long lasting, and it is a material known to be holding up well in tough climate or weather conditions, and against seismic activity. As a building material clay brick is believed to have been used as early as 7000 BC, where bricks made from clay or mud where laid out to dry in the sun.

With the invention of fired brick being dated to around $3500 \mathrm{BC}$, it became possible to make bricks even without long days of sun and higher temperatures, and the use of bricks as a building material could spread to areas with more challenging climates and days with less sun hours. The history of clay as a building material spans from the ancient Mesopotamia, to the Sumerians who built Ziggurats temples, the Egyptians built their households in clay, the Greeks and Romans used the clay, combined with different materials, stone, wooden, etc. On all the continents except for Antarctica clay has been a key building material throughout history. Perhaps being looked at as somewhat old fashioned in certain cultures today, this article aims to open eyes for why we perhaps should look again at this sophisticated material.

\section{FROM TRADITIONAL TO ECOLOGICAL ARCHITECTURE}

Romania's traditional architecture, inspired by Dacians and Roman culture, has inherited the old clay manufacturing techniques, which still today are able to showcase the durability of the local materials. As a characteristic feature of the traditional Romanian architecture, we can notice the ability of the masters from ancient times who have successfully combined these ecologic construction materials and this coexistence of stone, wood, clay, straws, even within the structure of the same building. Clay is a fireresistant material and it is as an example a perfect material for building stoves, chimneys and fireplaces.
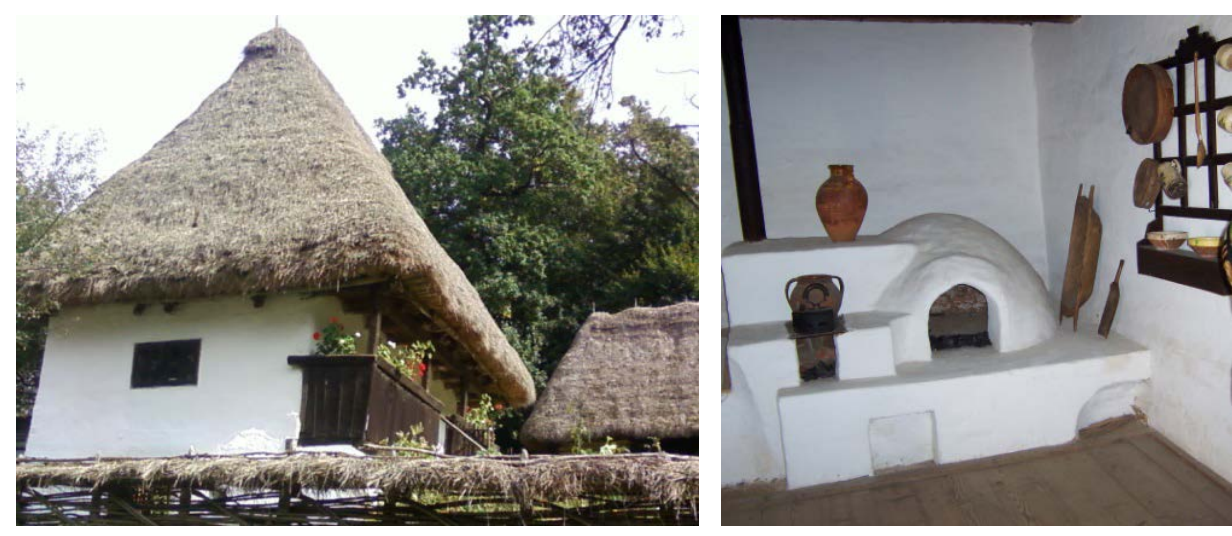

Figure 1, 2. Household, Apuseni, Transylvania. - Village Museum, Sibiu, Romania (author's photos)

Nowadays, if we also take from the treasury of folk architecture the construction techniques that have been tested for centuries, having a time-tested durability, and we 


\section{$7^{\text {th }}$}

Contemporary achievements in civil engineering 23-24. April 2019. Subotica, SERBIA

apply, in parallel, ecovillage principles, which are, in most part, consistent with the traditional ones, all of this will lead to a far superior result, being supported by the experience of past generations. [2]

The Romanian villages still preserve different types of traditional dwellings, and the new generations are going through the process of understanding the sustainability of the natural materials, and how they can be combined with recycled materials. In a Hungarian community, Covasna county, in Transylvania a young family proves the local clay isolation proprieties. Their house has been built by stacking used plastic bottles in the foundation wall and binding them together with clay. This provides an interesting mosaic of light on the inside of the cellar as the sun shines through the plastic bottles, and it is a good example of how another very durable material like plastic can be used in an environmentally friendly way as trash. In Romania plastic all too often ends up being discarded in nature, rather than being properly recycled. In this house is instead locked away in the construction of a building.
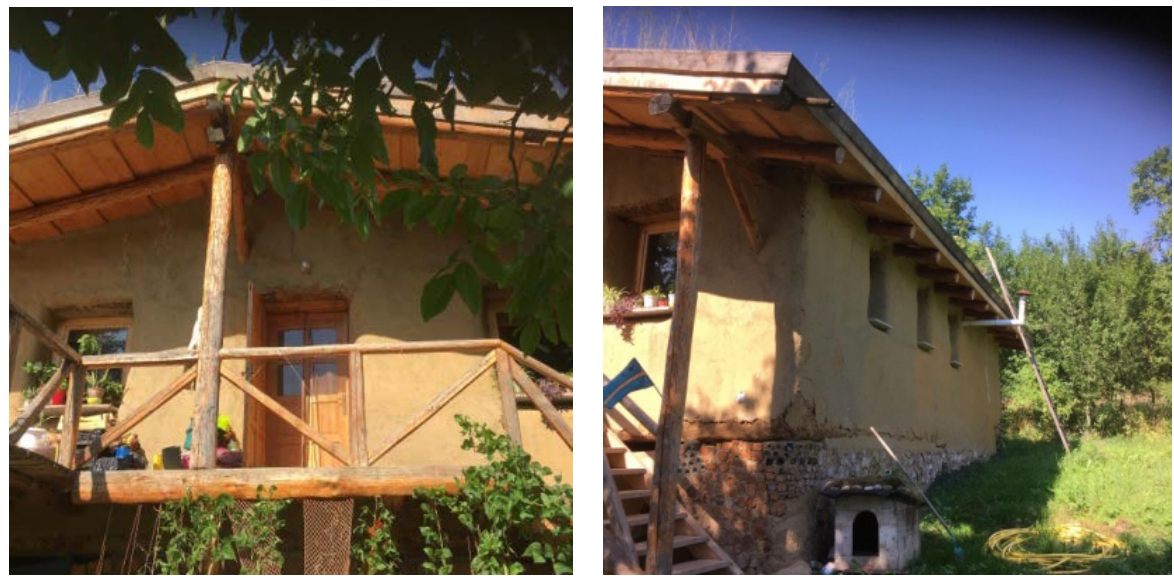

Figure 2, 3. House in Magherus, Covasna, Transylvania. Romania (author’s photos)

Why should one use clay for houses?

Clay as a building material for modern applications is very much overlooked compared to modern materials. The clay binds materials together, it allows for transport of humidity, it accumulates heat, it protects fibers, and it is stable. Many types have good anti-bacterial properties, and it is a good and healthy material which can solve many challenges. Unlike many modern materials, clay has a proven track record, and it is a material that should be placed high on the list of any architecture project with a safety first focus. Clay, and the ancient to modern techniques and knowledge of it, can also be masterfully combined with many types of more modern materials for making rooms and buildings which covers the whole specter of necessities for health and safety.

According to Julio E. Perez Diaz, a Chilean architect with vast experience from his work with clay in Chile and Norway, there are examples of clay plaster that is more than 5000 years old, and which still contains plant fibers that were used at the time, and which has been conserved in the clay. 
Савремена достигнућа у грађевинарству 23-24. април 2019. Суботица, СРБИЈА

The different chemical makeup and the properties of clay varies considerably from sites and regions. As Julio E. Perez Diaz has extensively discovered though his work on "Permaculture design methodology", he writes in his Permakultur Diplom work $\left(1^{\text {st }}\right.$ edition) 2014-2017: "All types of clay are different. This was thoroughly investigated through various mixes and types, and through the tests performed to make a good clay plaster. The knowledge acquired in a process with one type of clay, did not necessarily work with another type of clay. The task was to find a good recipe for clay plaster, which can work for everything, it was researched from the general to the special. Along the way I learned that there are different ways of making clay plaster, for the outside and for the inside of a building." [4]

Clay can be coloured, for bricks colouring has been an important part of architecture, with differences across time periods and between countries and cultures.

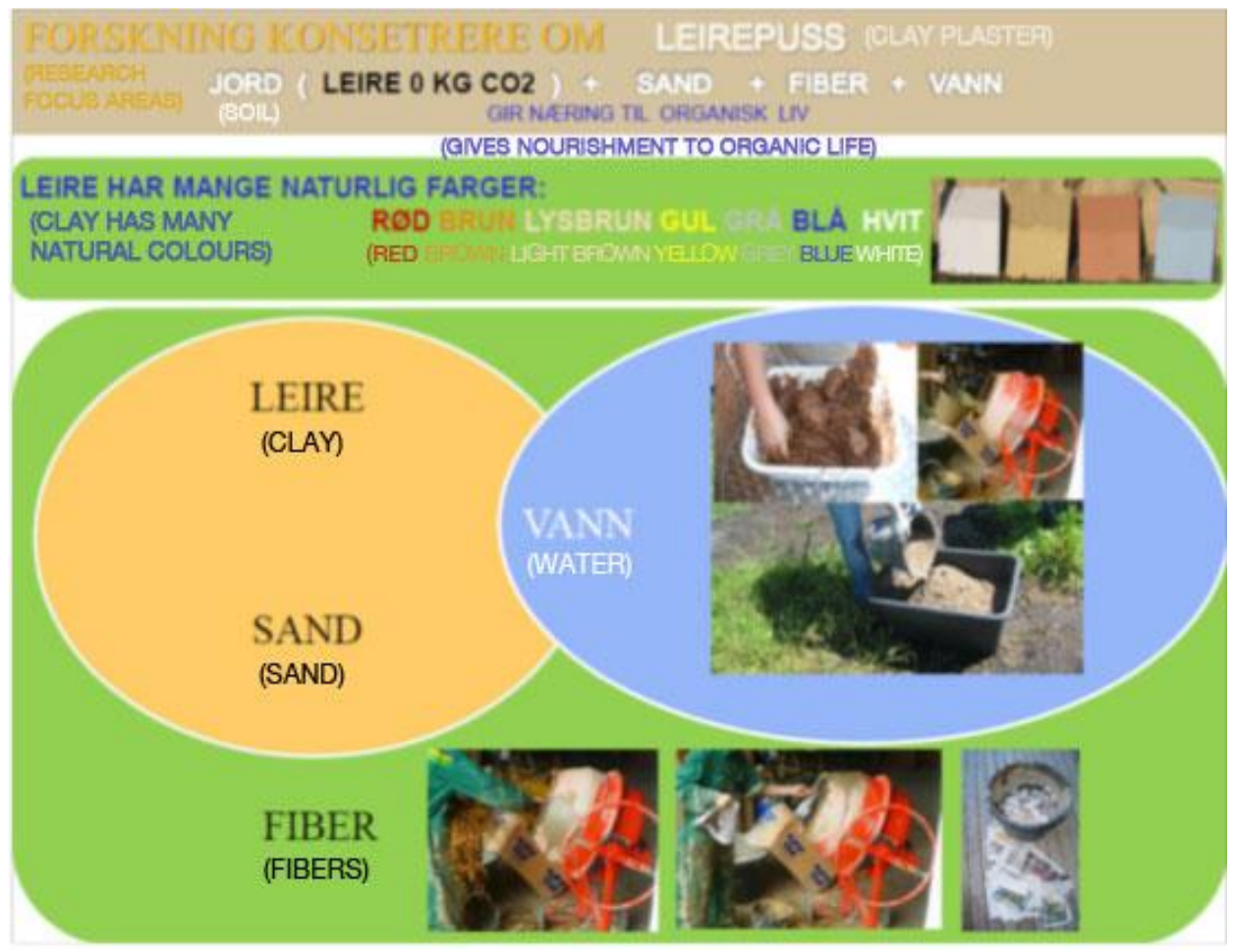

Figure 4. Julio E. Perez Diaz's methods for clay preparation

By using clay you are turning the building itself into a CO2 bank, holding onto CO2 contained through natural processes, and through the lifetime of the materials used in the building. Clay is easy to recycle, without an energy intensive or polluting process, and while not producing any waste. When dealing with non fired clay, if one demolishes a house made of clay as an example, all that is needed is to provide humidity to the material, and the clay will have the same properties as it had before, and you can use it again instantly. 
Contemporary achievements in civil engineering 23-24. April 2019. Subotica, SERBIA

Martin Michette, Rüdiger Lorenz and Christof Ziegert describe in the 2nd of August 2017 Heritage Science article "Clay barriers for protecting historic buidling from ground moisture intrusion", how compacted clay can be used to form a barrier in built heritage conservation. [6]

Clay is also a key component of loam. Having a layer of loam on the inside of building walls is a well tested method of controlling indoor air humidity. Loam combined with straw traditionally comes in two well known forms, rammed earth or unfired bricks, known as adobe.

Historically, clay has been known for having been used for centuries for medicinal purposes. Today it is being studied with a view to finding new ways of tackling harmful bacteria, in light of antibiotics resistance. Clay comes in colours from white to light grey, and yellow, brown-orange and towards deep red shades. Natural blue clay is known to contain chemically reduced iron and aluminum which can kill bacteria.

In one of the recent studies of clay and its anti-bacterial qualities researchers from Arizona State University and the Mayo Clinic, led by Dr. Robin Patel, documented how blue clay in particular may be effective at treating wounds. [7]

Kisameet clay have in other studies by the University of British Columbia in Vancouver, under laboratory conditions been found to kill dangerous bacteria such as MRSA. In a test of 16 bacteria from the ESKAPE group, all strains of bacteria were killed after 48 hours in a diluted suspension of Kisameet clay. [8]

\section{CONCLUSIONS}

Clay as a natural material building block has been shown over millenia to have marginal if any, negative health effects on its inhabitants. It can often be found locally, and in addition to being a cheap material to acquire and often to work with, it on several fronts have exceptional qualities for buildings that should be preferred over modern materials with shorter lifespans, and unknown health effects. When the clay over time changes and the colours fade, the clay can be repaired and reused.

Clay is a material that allows for breathing walls, ventilation, allowing for the transport of humidity out of the buildings body, while it can stop water from coming in. This is especially important in countries with shifting seasons and cold climate.

Clay still has many good applications in the kitchens and households, and as an alternative to materials that are more environmentally harmful to produce like plastics, and many other modern materials

This brief introductory information, prefaces the coming specialized extensive studies, both in the field of ecologic architecture as well as in the field of high-tech engineering, all could be integrated in planning the sustainable development of our traditional habitat. The specifities of each region, should lead to ecological answers in choosing the natural building materials and adapting to the socio-cultural and preserving the population health conditions. 
7.

МЕЂУНАРОДНА КОНФЕРЕНЦИЈА

Савремена достигнућа у грађевинарству 23-24. април 2019. Суботица, СРБИЈА

\section{REFERENCES}

[1] Norberg-Shultz C.: Existence, Space \& Architecture. Praeger Publishers, London, 1971.

[2] Chițonu G.C.: Sustainable development reflected in the values of traditional architecture. Proceedings of the INTERNATIONAL SCIENTIFIC CONFERENCE CIBv-2010 , 2010 p. 34

[3] Berge, B., et al.:The Ecology of Building Materials, 2nd ed.; Elsevier: Italy, 2009; p. 427.

[4] Perez Diaz J.E. : Permaculture design methodology, Permakultur Diplom $1^{\text {st }}$, Norway, 2014, p.18

[5] Cazacu C., Chiţonu G.C.: Ecological criteria considering the connections between the construction, building-site and the spatial planning development, The 3rd China-Romania Science and Technology Seminar CRSTS 2018, Brasov, Romania, 2018

[6] https://heritagesciencejournal.springeropen.com/articles/10.1186/s40494-017-0144-3

[7] https://www.sciencedirect.com/science/article/pii/S0924857918302097

[8]https://www.researchgate.net/publication/292073744_Kisameet_Clay_Exhibits_Poten t_Antibacterial_Activity_against_the_ESKAPE_Pathogens 